\title{
Pengetahuan dan Pola Swamedikasi Penggunaan Obat Tradisional dan Cara Pengobatan Tradisional Sebagai Terapi Komplementer di Wilayah Kerja Yandu Wredasari 07, Warungboto, Umbulharjo, Yogyakarta
}

\author{
Wahyu Tusi Wardania, ${ }^{*}$, Muhammad Muhlis ${ }^{b, 1}$ \\ a Program Studi Ilmu Farmasi, STIKes Surya Global Yogyakarta, Yogyakarta, JawaTengah, Indonesia \\ b Fakultas Farmasi, Universitas Ahmad Dahlan, Yogyakarta, Jawa Tengah, Indonesia \\ tusy.wardani@gmail.com \\ *korespondensi penulis
}

INFO ARTIKEL

ABSTRAK

Diterima:

24-06-2020

Disetuji:

04-07-2020

\section{Kata kunci:}

Swamedikasi;

Obat tradisional;

Cara pengobatan

tradisional;

Terapi komplementer.

Meningkatnya tingkat pendidikan, informasi dan kesadaran masyarakat akan pentingnya arti sehat, mendorong masyarakat untuk melakukan swamedikasi. Termasuk swamedikasi menggunakan obat tradisional dan cara pengobatan tradisional sebagai terapi komplementer semakin meningkat. Penelitian ini bertujuan untuk mengetahui gambaran pengetahuan dan pola swamedikasi menggunakan obat tradisional dan cara pengobatan tradisional sebagai terapi komplementer pada Yandu Wredasari 07, Warungboto, Umbulharjo, Kota Yogyakarta. Penelitian ini merupakan penelitian observasional yang bersifat non eksperimen, Sampel yang digunakan dalam penelitian ini adalah anggota Yandu Wredasari 07, Warungboto, Umbulharjo, Kota Yogyakarta dan memenuhi kriteria sampel yang ditetapkan oleh peneliti. Pengambilan sampel dilakukan tanpa acak (nonprabability sampling) dengan teknik pengambilan consecutive sampling. Responden yang pernah melakukan pengobatan komplementer dengan obat tradisional sebanyak 81,6\%. 83,3\% diantaranya merasakan tidak muncul efek samping obat selama menggunakan obat tradisional. Sedangkan Responden yang pernah melakukan pengobatan komplementer dengan cara tradisional sebanyak $39,5 \%$. Hanya satu yang merasakan efek samping yaitu dari pijat tradisional, muncul warna agak biru, njarem dan linu linu.

Keywords:

Swamedication;

Traditional medicine;

Traditional treatment methods;

Complementary therapy.

\section{ABSTRACT}

The increasing level of education, information and public awareness of the importance of healthy meaning, encourages people to carry out swamedication. Including self-medication using traditional medicine and ways of traditional medicine as complementary therapies is increasing. This study aims to determine the description of knowledge and patterns of self-medication using traditional medicine and traditional medicine as a complementary therapy in Yandu Wredasari 07, Warungboto, Umbulharjo, Yogyakarta City. This study was an observational study that was non-experimental in nature. The sample used in this study was a member of Yandu Wredasari 07, Warungboto, Umbulharjo, Yogyakarta City and met the sample criteria set by the researcher. Sampling is done without random (nonprabability sampling) with consecutive sampling techniques. Respondents who had taken complementary medicine with traditional medicine were $81.6 \%$. $83.3 \%$ of them felt there were no side effects of drugs while using traditional medicines. While the respondents who had done complementary medicine in the traditional way were $39.5 \%$. Only one felt the side effects of traditional massage, appearing a little blue, njarem and rheumatic pain. 


\section{Pendahuluan}

Dengan kemajuan pendidikan dan informasi, mayoritas masyarakat pernah melakukan swamedikasi. Dalam sebuah penelitian, sejumlah 640 sampel di Kota Yogyakarta dipilih secara klaster acak pada periode Maret-Mei 2010, sebanyak 100\% dari responden tersebut pernah melakukan swamedikasi. Responden yang membeli obat modern sebanyak $86 \%$ dan obat tradisional sebanyak I4\% (Widayati, 2013). Hal ini menunjukkan bahwa mayoritas masyarakat di Kota Yogyakarta biasa melakukan swamedikasi, I $4 \%$ diantaranya, menggunakan obat tradisional. WHO merekomendasi penggunaan obat tradisional termasuk herbal dalam pemeliharaan kesehatan masyarakat, pencegahan dan pengobatan penyakit, terutama untuk penyakit kronis, penyakit degeneratif dan kanker. WHO juga mendukung upaya-upaya dalam peningkatan keamanan dan khasiat dari obat tradisional (WHO, 2003).

Persepsi masyarakat terhadap pengobatan komplementer dapat ditinjau dari beberapa aspek, antara lain metode pengobatan, khasiat, dan biaya. Dalam penelitian Setyaningsih 2006, diperoleh hasil persepsi negatif terhadap pengobatan komplementer yaitu sebanyak 61\%. Berdasarkan distribusi tersebut menunjukkan bahwa sebagian besar masyarakat beranggapan bahwa pengobatan komplementer memiliki resiko yang besar serta sulit untuk dipercayai dan juga masyarakat yang mengatakan pengobatan komplementer masih diragukan hasilnya. Ada 39\% responden yang memiliki persepsi positif terhadap pengobatan komplementer. Dengan adanya pengobatan komplementer sangat membantu masyarakat dalam memperoleh kesehatan. Serta anggapan masyarakat untuk mendapatkan atau menemukan pengobatan komplementer tidaklah serumit dengan pengobatan medis. (Setyaningsih, 2006)

Penggunaan obat bahan alam sebagai terapi komplementer sudah sangat berkembang dan diperhitungkan. Hal ini disebabkan adanya beberapa faktor, yaitu meningkatnya tingkat pendidikan, informasi dan kesadaran masyarakat akan pentingnya arti sehat dan harga obat tradisional yang dianggap lebih murah dengan efek samping yang dianggap lebih sedikit. Penelitian ini bertujuan untuk mengetahui gambaran pengetahuan dan pola swamedikasi menggunakan obat tradisional sebagai terapi komplementer pada Yandu Wredasari 07, Warungboto, Umbulharjo, Kota Yogyakarta

\section{Metode}

Penelitian ini merupakan jenis penelitian observasional yang bersifat non eksperimen. Penelitian ini bertujuan untuk mengetahui gambaran pola swamedikasi menggunakan obat tradisional sebagai terapi komplementer pada anggota yandu Wredasari 07, Warungboto, Umbulharjo, Kota Yogyakarta.

Populasi pada penelitian ini adalah seluruh responden yang menjadi anggota yandu Wredasari 07. Sampel dalam penelitian ini adalah semua anggota Yandu Wredasari 07, yang hadir pada saat yandu bulan Agustus 2019. Kriteria inklusi dalam penelitian ini adalah responden yang hadir pada saat yandu bulan Agustus 2019 dan responden yang punya penyakit degenerative (Hipertensi, diabetes dan kolesterol). Kriteria eksklusi dalam penelitian ini adalah: Responden yang sehat dan Responden yang tidak bersedia menjadi responden.

Penelitian ini akan dilakukan pada bulan April 2019 - Agustus 2019. Data primer didapatkan langsung dari responden melalui kuesioner yang diberikan oleh peneliti. Data sekunder didapatkan dari Puskesmas Umbulharjo 2, Kota Yogyakarta. Data yang terkumpul diolah dan di analisis secara deskriptif.

\section{Hasil dan pembahasan}

Penelitian ini mengambil responden yang hadir pada saat posyandu lansia di bulan Agustus, adapun jumlah responden sebanyak 38. Semua responden memenuhi syarat sebagai sampel karena semua yang hadir memiliki penyakit degenerative.

Karakteristik responden pada penelitian ini terdiri dari: umur, jenis kelamin, tingkat pendidikan terakhir dan hasil tes kesehatan. Tersaji pada Tabel I dibawah ini.

Tabel I. Distribusi Karakteristik Responden

Berdasarkan, Umur, Jenis Kelamin, Tingkat Pendidikan Terakhir Dan Hasil Tes Kesehatan

\begin{tabular}{cccc}
\hline No & $\begin{array}{c}\text { Karakteristik } \\
\text { responden }\end{array}$ & $\begin{array}{c}\text { Frekuens } \\
\text { i }\end{array}$ & $\begin{array}{c}\text { Persentase } \\
(\%)\end{array}$ \\
\hline I. & Umur & & \\
\cline { 2 - 4 } & a. $26 \mathrm{~s} / \mathrm{d} 35$ & 3 & 7,9
\end{tabular}


Tabel I. Distribusi Karakteristik Responden Berdasarkan, Umur, Jenis Kelamin, Tingkat Pendidikan Terakhir Dan Hasil Tes Kesehatan

\begin{tabular}{cccc}
\hline No & $\begin{array}{c}\text { Karakteristik } \\
\text { responden }\end{array}$ & $\begin{array}{c}\text { Frekuens } \\
\text { i }\end{array}$ & $\begin{array}{c}\text { Persentase } \\
\text { (\%) }\end{array}$ \\
\hline 2. & b. 36 s/d 45 & 2 & 5,3 \\
& & & \\
\hline & c.46 s/d 55 & 4 & I0,5 \\
& & & \\
\hline & d. 56 s/d 65 & I5 & 39,5 \\
\hline \multirow{4}{*}{ e. $>$ 65 th } & I4 & 36,8 \\
\hline 3. Jenis kelamin & & \\
\cline { 2 - 4 } & a. Laki laki & 9 & 23,7 \\
\cline { 2 - 4 } & b. Perempuan & 29 & 76,3
\end{tabular}

\begin{tabular}{|c|c|c|c|}
\hline 4. & $\begin{array}{l}\text { Tingkat } \\
\text { pendidikan }\end{array}$ & & \\
\hline & a. SD & 8 & 20,8 \\
\hline & b. SMP & IO & 26 \\
\hline & c. SMA & 6 & I5,6 \\
\hline & d. D III & I & 2,6 \\
\hline & e. SI & 8 & 20,8 \\
\hline & f. S2 & I & 2,6 \\
\hline & g. Lain-lain & 4 & 10,4 \\
\hline $\begin{array}{c}\text { To } \\
\text { tal }\end{array}$ & & 38 & 100 \\
\hline 5. & $\begin{array}{ll}\text { Hasil } & \text { Tes } \\
\text { Kesehatan } & \\
\end{array}$ & & \\
\hline & $\begin{array}{l}\text { a. Tekanan } \\
\text { darah }\end{array}$ & & \\
\hline & - Rendah & - & - \\
\hline & - Normal & I4 & 36,4 \\
\hline & - Tinggi & 24 & 62,4 \\
\hline
\end{tabular}

b. Kadar gula

darah sewaktu

\begin{tabular}{lcc}
\hline - Rendah & 2 & 5,26 \\
\hline - Normal & $3 \mathrm{I}$ & 80,6 \\
\hline - Tinggi & 5 & $\mathrm{I} 3$ \\
\hline c. Kolesterol & & \\
\hline - Rendah & - & - \\
\hline - Normal & I7 & 44,2 \\
\hline - Tinggi & 2I & 54,6
\end{tabular}

Berdasarkan Tabel I diatas, terlihat bahwa mayoritas peserta yandu lansia adalah usia 56 tahun keatas sebesar 76,3\%.

Kelompok lansia awal belum banyak yang hadir dan aktif dalam yandu lansia. Kelompok lansia akhir yang hadir sebanyak 39,5\% dan manula sebanyak $36,8 \%$.
Berdasarkan jenis kelamin mayoritas responden adalah perempuan yaitu sebanyak $76,3 \%$. Sedangkan yang laki laki hanya 23,7\%. Hal ini disebabkan karena keterlibatan perempuan dalam sejumlah kegiatan sosial kemasyarakatan biasanya lebih tinggi dibanding dengan laki laki.

Berdasarkan karakteristik tinggkat pendidikan terakhir, urutan pertama adalah lulusan SMP sebesar 26\%. Urutan kedua, lulusan SD dan SI sama besarnya yaitu sebanyak 20,8\%.

Berdasarkan hasil tes tekanan darah, diperoleh data, tidak ada responden yang menderita hipotensi. Responden dengan tekanan darah normal sebanyak 36,4\% dan yang menderita tekanan darah tinggi sebanyak 62,4\%. Tekanan darah yang normal sekitar 90/60 $\mathrm{mmHg}$ hingga I20/80 mmHg.

Berdasarkan hasil tes Kadar gula darah sewaktu, diperoleh data, ada 5,3\% responden yang kadar gulanya rendah. Sekitar 80,6 \% responden memiliki kadar gula yang normal. Dan I3\% responden yang menderita diabetes atau kadar gulanya diatas normal.

Berdasarkan hasil tes Kolesterol, diperoleh data, 44,2\% responden dalam kondisi normal dan $54,6 \%$ responden mengalami kadar kolesterol yang tinggi.

\section{Pengobatan dengan Obat Modern}

Tabel 2. Distribusi Tempat Pengobatan Rutin Responden

\begin{tabular}{|ll|c|c|}
\hline & Kategori & $\begin{array}{c}\text { Frekuensi } \\
(\mathrm{f})\end{array}$ & $\begin{array}{c}\text { Presentase } \\
(\%)\end{array}$ \\
\hline A. & Rumah Sakit & 8 & 20,8 \\
B. & Puskesmas & $\mathrm{I} 8$ & 46,8 \\
C. & Yandu Lansia & 6 & $\mathrm{I} 5,6$ \\
D. Klinik & 2 & 5,2 \\
E. Bidan & 4 & $\mathrm{I} 0,4$ \\
F. $\quad \ldots . . . . .$. & & \\
\hline Total & 38 & $\mathrm{I} 00$ \\
\hline
\end{tabular}

Mayoritas responden (46,8\%) memilih puskesmas sebagai tempat untuk pengobatan rutin. Hal ini bisa disebabkan karena fasilitas puskesmas, jarak yang dekat dan peraturan pemerintah tentang pemeriksaan berjenjang. Yandu Wredasari 07, Warungboto masuk dalam wilayah kerja Puskesmas Umbulharjo I. Di puskesmas tersebut terdapat fasilitas pemeriksaan dokter, psikolog dan laboratorium. Jarak antara rumah warga anggota Yandu Wredasari 07, 
Warungboto dengan Puskesmas Umbulharjo I hanya I km.

Tabel 3. Data Pengetahuan Responden Tentang Manfaat Obat Yang Diberikan Dari Dokter

\begin{tabular}{|c|c|c|}
\hline Kategori & $\begin{array}{l}\text { Frekuensi } \\
\text { (f) }\end{array}$ & $\begin{array}{c}\text { Presentase } \\
(\%)\end{array}$ \\
\hline Diberi obat & 30 & 76,7 \\
\hline a. Tahu manfaat & 23 & \\
\hline b. tidak tahu & 7 & \\
\hline Tidak diberi obat & 8 & 23,3 \\
\hline Total & 38 & 100 \\
\hline
\end{tabular}

Berdasarkan data di atas, bisa kita ketahui bahwa mayoritas responden, sebesar 59,8\% mengetahui khasiat dari obat yang diberikan oleh dokter. Selebihnya yaitu sebanyak I8,2\% responden tidak mengetahui manfaat dari obat yang diberikan oleh dokter.

Tabel 4. Distribusi Pendidikan Responden Yang Tidak Mengetahui Manfaat Dari Obat Yang Diberikan Dari Dokter

\begin{tabular}{lll}
\hline $\begin{array}{c}\text { Pendidikan } \\
\text { terakhir }\end{array}$ & $\begin{array}{c}\text { Frekuensi } \\
\text { (f) }\end{array}$ & $\begin{array}{c}\text { Presentase } \\
(\%)\end{array}$ \\
\hline a. SD & 4 & $57, \mathrm{I}$ \\
\hline b. SMP & 2 & 28,6 \\
\hline c. SMA & - & \\
\hline d. D III & - & \\
\hline e. SI & - & \\
\hline f. S2 & - & I4,3 \\
\hline $\begin{array}{l}\text { g. Lain-lain } \\
\text { (tidak sekolah) }\end{array}$ & I & \\
\hline Total & 7 & I00 \\
\hline
\end{tabular}

Dari tabel 4 diketahui bahwa, responden yang tidak mengetahui manfaat dari obat yang diberikan oleh dokter, semua berpendidikan rendah. Hal ini menguatkan pendapat bahwa swamedikasi akan benar atau mendekati benar jika masyarakat punya latar belakang pendidikan yang tinggi.

\section{Pengobatan Komplementer Menggunakan Obat Tradisional}

Tabel 5. Distribusi Penggunaan Obat Modern Dan Obat Tradisional Untuk Mengobati Penyakit Diderita

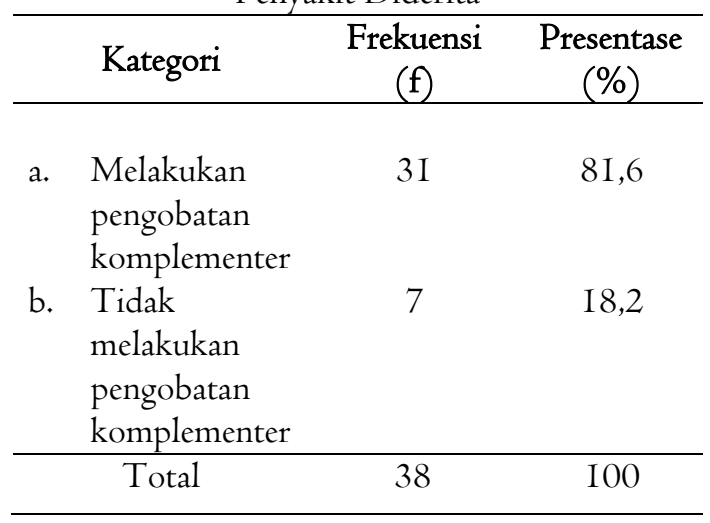

Tabel 5 mengenai distribusi penggunaan obat modern dan obat tradisional untuk mengobati penyakit diderita. Sebesar 81,6\% responden melakukan pengobatan komplementer dengan menggunakan obat tradisional.

Penggunaan obat tradisional meningkat mungkin disebabkan adanya beberapa faktor, yaitu meningkatnya tingkat pendidikan, informasi dan kesadaran masyarakat akan pentingnya arti sehat dan harga obat tradisional yang dianggap lebih murah dengan efek samping yang dianggap lebih sedikit.

Tabel 6. Penggunaan Obat Tradisional Untuk Mengobati Penyakit Diderita

\begin{tabular}{|c|c|c|}
\hline No & $\begin{array}{r}\text { Obat } \\
\text { Tradisional }\end{array}$ & $\begin{array}{c}\text { Penyakit } \\
\text { Yang Diderita }\end{array}$ \\
\hline I. & Madu pahit 99 bima & Kolesterol \\
\hline 2. & Suruh china & Kolesterol \\
\hline 3. & Buah pace & $\begin{array}{l}\text { Hipertensi, } \\
\text { kolesterol }\end{array}$ \\
\hline 4. & Madu pahit & $\begin{array}{l}\text { Hipertensi, } \\
\text { DM, } \\
\text { kolesterol }\end{array}$ \\
\hline 5. & $\begin{array}{l}\text { Sereh dan jahe } \\
\text { rebusan }\end{array}$ & $\begin{array}{l}\text { Hipertensi } \\
\text { kolesterol }\end{array}$ \\
\hline 6. & Pare dirajang diseduh & $\begin{array}{l}\text { Hipertensi, } \\
\text { DM }\end{array}$ \\
\hline 7. & Madu klengkeng & DM \\
\hline 8. & Madu tj & Kolesterol \\
\hline 9. & $\begin{array}{l}\text { Jamu peres tradisional } \\
\text { kotagede }\end{array}$ & $\begin{array}{l}\text { Hipertensi } \\
\text { kolesterol }\end{array}$ \\
\hline IO. & Madu seribu bunga & $\begin{array}{l}\text { Hipertensi } \\
\text { kolesterol }\end{array}$ \\
\hline II. & Madu lanceng putih & DM \\
\hline
\end{tabular}


Tabel 6. Penggunaan Obat Tradisional Untuk Mengobati Penyakit Diderita

\begin{tabular}{|c|c|c|}
\hline No & $\begin{array}{r}\text { Obat } \\
\text { Tradisional }\end{array}$ & $\begin{array}{c}\text { Penyakit } \\
\text { Yang Diderita }\end{array}$ \\
\hline 12. & Jamu pahitan & Hipertensi \\
\hline 13. & $\begin{array}{l}\text { Jamu racikan sendiri } \\
\text { (dulu) }\end{array}$ & Hipertensi \\
\hline $\mathrm{I} 4$. & $\begin{array}{l}\text { Jeruk nipis diiris } \\
\text { diseduh air panas }\end{array}$ & $\begin{array}{l}\text { Hipertensi, } \\
\text { DM, } \\
\text { kolesterol }\end{array}$ \\
\hline I5. & $\begin{array}{l}\text { Jahe merah, bw } \\
\text { lanang, jeruk lemon, } \\
\text { cuka apel, diblender } \\
\text { direbus disaring beri } \\
\text { madu }\end{array}$ & $\begin{array}{l}\text { DM } \\
\text { kolesterol }\end{array}$ \\
\hline 16. & Jamu, seduh mbs & $\begin{array}{l}\text { Hipertensi, } \\
\text { DM, } \\
\text { kolesterol } \\
\end{array}$ \\
\hline 17. & $\begin{array}{l}\text { Binahong } 3 \text { lbr } \\
\text { diremas2 diberi air } \\
\text { panas }\end{array}$ & Kolesterol \\
\hline I8. & Madu pahit & Hipertensi \\
\hline 19. & Jeruk nipis peras & $\begin{array}{l}\text { Hipertensi } \\
\text { kolesterol }\end{array}$ \\
\hline 20. & Jipang kukus & Kolesterol \\
\hline $2 \mathrm{I}$ & $\begin{array}{l}\text { Daun nangka sabrang } \\
\text { / dau sirsak / } \\
\text { ketumbar + daun } \\
\text { manis jangan }\end{array}$ & Hipertensi \\
\hline 22. & $\begin{array}{l}\text { Beras kencur dan } \\
\text { paitan, seminggu } 2 x \text {; } \\
\text { daun sirsak diseduh, I } \\
\text { minggu Ix }\end{array}$ & $\begin{array}{l}\text { Hipertensi } \\
\text { kolesterol }\end{array}$ \\
\hline 23. & Habatussauda & DM \\
\hline 24. & $\begin{array}{l}\text { Tumbar rebus } 2 \mathrm{sdm} \\
+ \text { air I gls) }\end{array}$ & $\begin{array}{l}\text { Hipertensi, } \\
\text { DM } \\
\text { kolesterol }\end{array}$ \\
\hline 25. & $\begin{array}{l}\text { Antangin, jamu beras } \\
\text { kencur }\end{array}$ & $\begin{array}{l}\text { Hipertensi } \\
\text { kolesterol }\end{array}$ \\
\hline 26 & $\begin{array}{l}\text { Daun tapak liman } \\
\text { (obat bebas) }\end{array}$ & $\begin{array}{l}\text { Hipertensi } \\
\text { kolesterol }\end{array}$ \\
\hline 27. & $\begin{array}{l}\text { Rebusan daun sirsak } 7 \\
\text { lbr } 2 \text { gelas jd I gls }\end{array}$ & Hipertensi \\
\hline 28. & $\begin{array}{l}\text { Air ketumbar }+ \text { madu } \\
\text { seminggu } 2 x \text {, sledri } \\
\text { direbus seminggu } 2 x \text {, } \\
\text { kurma nabi seminggu } \\
2 x \text { (selang seling) }\end{array}$ & Kolesterol \\
\hline 29. & $\begin{array}{l}\text { Daun salam } 7 \text { lbr } \\
\text { direbus, sledri direbus, } \\
\text { daun sirsak } 3 \text { hari } \\
\text { sekali (selang seling) }\end{array}$ & $\begin{array}{l}\text { Hipertensi } \\
\text { kolesterol }\end{array}$ \\
\hline 30. & Cabe puyang pil kita & Hipertensi \\
\hline
\end{tabular}

\begin{tabular}{ll} 
3I. Madu sialang hutan & Hipertensi \\
dan sumbawa super & \\
\hline
\end{tabular}

Tabel 6 memberi ganbaran tentang penggunaan obat tradisional untuk mengobati penyakit diderita. Masyarakat beranggapan bahwa pada saat mereka sakit mereka menginginkan pengobatan yang bisa membantu menyembuhkan penyakitnya. Ada $29 \%$ masyarakat yang menggunakan madu sebagai pengobatan penyakitnya.

Tabel 7. Distribusi Bentuk Obat Tradisional Tradisional Yang Dikonsumi Responden

\begin{tabular}{lcc}
\hline \multicolumn{1}{c}{ Kategori } & $\begin{array}{c}\text { Frekuensi } \\
(\mathrm{f})\end{array}$ & $\begin{array}{c}\text { Presentase } \\
(\%)\end{array}$ \\
\hline a.Rajangan & 7 & $\mathrm{I} 8,2$ \\
b. Pil & - & \\
c. tablet & 2 & 5,2 \\
d. kapsul & $\mathrm{I}$ & 2,6 \\
e. serbuk & - & - \\
f. larutan & $\mathrm{I} 4$ & 36,4 \\
g. Lain-lain & $\mathrm{I} 3$ & 33,8 \\
\hline Total & & \\
\hline
\end{tabular}

Tabel 7 tentang distribusi bentuk obat tradisional tradisional yang dikonsumi responden. Bentuk obat tradisional sangat bervariasi, mulai dari yang masih dilakukan dengan cara sederhana seperti direbus, dipipis atau diseduh sampai dengan yang menggunakan teknologi maju seperti kapsul, tablet dll. Bentuk obat tradisional yang paling banyak dikonsumsi oleh responden yaitu berupa larutan yaitu sebesar 36,4\%.

Tabel 8. Distribusi Pengetahuan Dosis Obat

Tradisional Pada Pasien Yang Menggunakan Terapi Komplementer

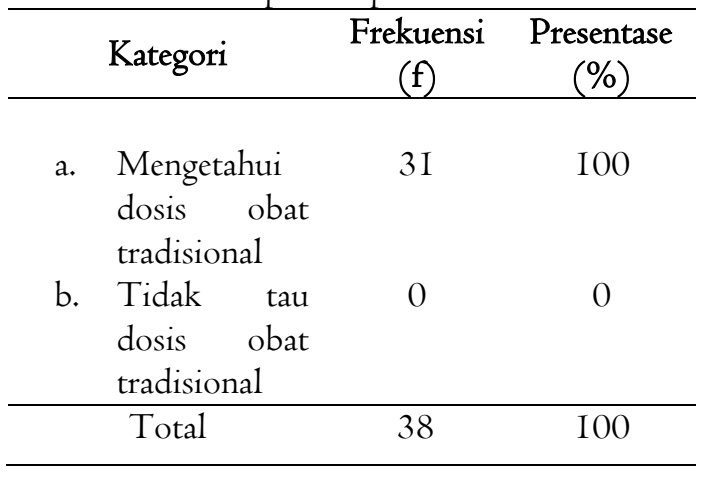

Dari tabel diatas, dapat disimpulkan bahwa semua responden mengetahui dosis obat tradisional yang digunakan. Informasi dosis bisa didapatkan dari kemasan obat atau dari teman yang menginformasikan. 
Tabel 9. Distribusi Lama Penggunaan Obat Tradisional.

\begin{tabular}{|c|c|c|}
\hline Kategori & $\begin{array}{c}\text { Frekuensi } \\
\text { (f) }\end{array}$ & $\begin{array}{c}\text { Presentase } \\
(\%)\end{array}$ \\
\hline a. I hari saja & 3 & 7,8 \\
\hline b. $2-3$ hari & I & 2,6 \\
\hline c. I minggu & I & 2,6 \\
\hline d. Sebulan & 9 & 23,4 \\
\hline e. Sampai sembuh & 17 & 44,2 \\
\hline f. Lain lain & 7 & $\mathrm{I} 8,2$ \\
\hline Total & 38 & 100 \\
\hline
\end{tabular}

Dari tabel diatas dapat diketahui bahwa mayoritas responden menggunakan obat tradisional sampai sembuh $(44,2 \%)$. Penduduk yang mengeluh sakit dan melakukan pengobatan sendiri menggunakan obat cenderung menurun dengan meningkatnya lama sakit, tetapi yang menggunakan obat tradisional dan cara tradisional cenderung meningkat dengan meningkatnya lama sakit. (Supardi, 20I5)

Tabel 10. Distribusi Sumber Informasi Penggunaan Obat Tradisional

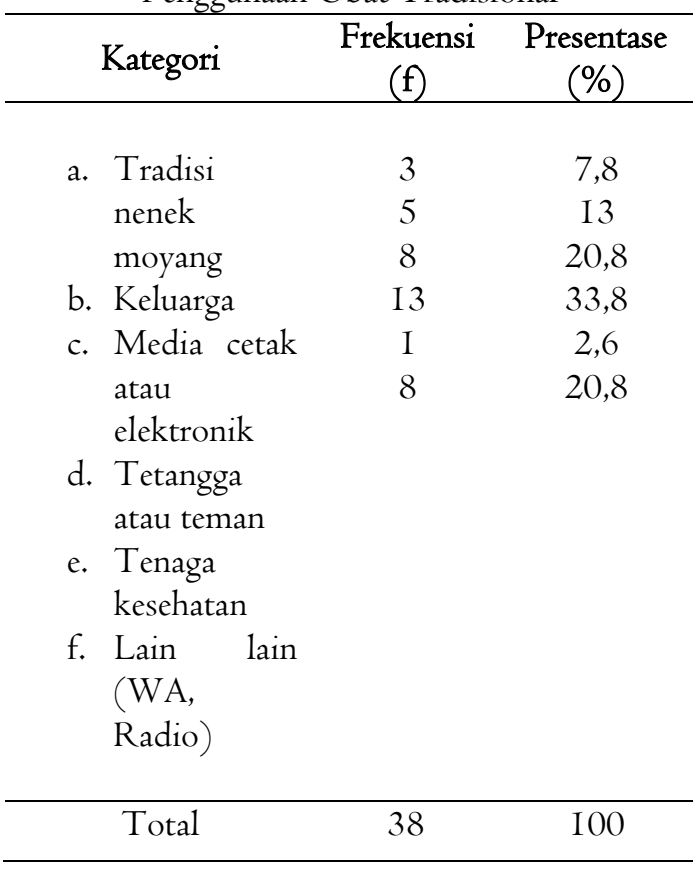

Dari tabel diatas, dapat diketahui bahwa Sumber Informasi Penggunaan Obat Tradisional yang paling besar berasal dari tetangga atau teman $(33,8 \%)$. Tetangga atau teman memiliki peran yang penting dalam memberikan informasi mengenai obat tradisional.
Tabel II. Distribusi Cara Mendapatkan Obat Tradisional

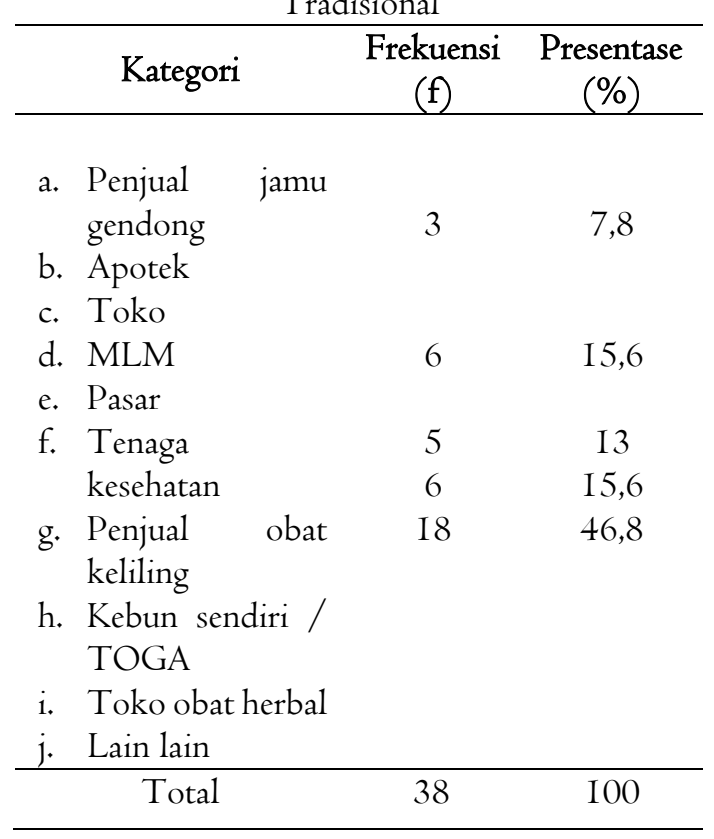

Tabel II memberi gambaran tentang cara mendapatkan obat tradisional. Sebanyak 46,8\%, responden mendapatkan dari toko herbal karena lebih mudah, lengkap dan informasi yang didapatkan juga bias dipercaya. Berbeda dengan penelitian Ismiyana 2013, dalam penelitiannya diperoleh data mayoritas masyarakat mendapatkan obat tradisional dari jamu gendong yaitu sebesar $45,8 \%$.

Tabel I2. Alasan Menggunakan Obat Tradisional

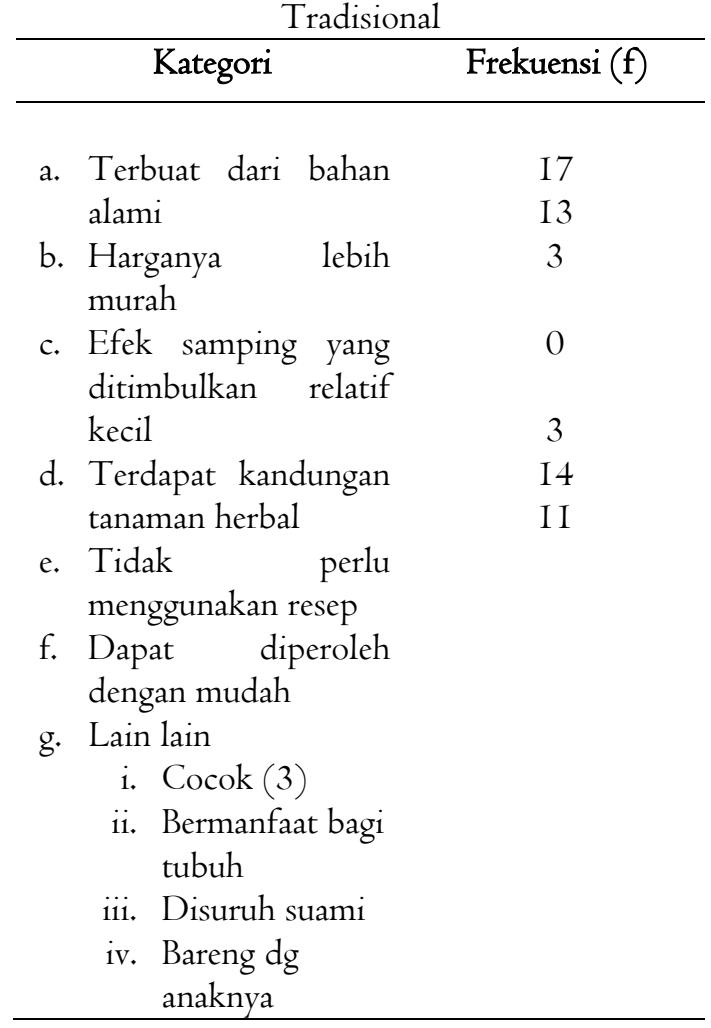


v. Sudah turun temurun

vi. Bujukan sang ustad

vii. Sunah nabi

viii. Takut ke dokter

ix. Untuk menjaga stamina

Tabel 13. Efek Yang Dirasakan Selama Menggunakan Obat Tradisional

\begin{tabular}{|c|c|}
\hline No & Efek Yang Dirasakan \\
\hline I. & Lebih terasa enak, maag jarang kumat \\
\hline 2 . & Di badan jadi ringan \\
\hline 3. & Di badan terasa enak, ringan \\
\hline 4. & Terutama meredakan flu, batuk pilek \\
\hline 5. & Menjaga kadar gula supaya tidak naik \\
\hline 6. & Di badan fresh, menjaga stamina \\
\hline 7. & Tidak gampang sakit \\
\hline 8. & $\begin{array}{l}\text { Ringan di badan, mencegah tidak } \\
\text { mudah sakit }\end{array}$ \\
\hline 9. & $\begin{array}{l}\text { Saat puasa jadi lebih kuat kalau } \\
\text { sahurnya minum madu }\end{array}$ \\
\hline IO. & Di badan terasa ringan \\
\hline II. & $\begin{array}{l}\text { BAB lancar, badan jadi ringan, tidur } \\
\text { nyenyak }\end{array}$ \\
\hline $\mathrm{I} 2$. & $\begin{array}{l}\text { Untuk menghancurkan flek } 2 \mathrm{dlm} \\
\text { pembuluh darah }\end{array}$ \\
\hline I3. & $\begin{array}{l}\text { Efek langsung terasa, jika kaki terasa } \\
\text { berat }\end{array}$ \\
\hline I4. & Menghilangkan mual \\
\hline I5. & $\begin{array}{l}\text { Untuk meluruhkan lemak dan } \\
\text { menurunkan kolesterol }\end{array}$ \\
\hline 16. & Efeknya langsung terasa \\
\hline 17. & Di badan jadi lebih ringan \\
\hline I8. & Untuk menurunkan kolesterol \\
\hline 19. & Melancarkan peredaran darah \\
\hline 20. & Terutama kalau meriang \\
\hline $2 \mathrm{I}$. & $\begin{array}{l}\text { Kalau asam urat kumat, minum obat ini } \\
\text { jadi lebih enak }\end{array}$ \\
\hline 22. & $\begin{array}{l}\text { Enak dibadan, mengurangi efek karena } \\
\text { merokok }\end{array}$ \\
\hline 23. & Tidak pegal2 di bahu \\
\hline 24. & $\begin{array}{l}\text { Kolesterol jadi turun, tekanan darah } \\
\text { relatif stabil }\end{array}$ \\
\hline 25. & $\begin{array}{l}\text { Di badan lebih segar, menjaga kadar } \\
\text { gula dalam darah }\end{array}$ \\
\hline
\end{tabular}

Tabel I4. Efek Samping Yang Dirasakan Setelah Minum Obat Tradisional

\begin{tabular}{|c|c|c|}
\hline Kategori & $\begin{array}{c}\text { Freku } \\
\text { ensi } \\
\text { (f) }\end{array}$ & $\begin{array}{c}\text { Presen } \\
\text { tase } \\
(\%)\end{array}$ \\
\hline \multicolumn{2}{|c|}{ Tidak muncul efek sampingo } & 83,3 \\
\hline b. Mengantuk & $\mathrm{I}$ & 2,78 \\
\hline c. Mual & $\mathrm{I}$ & 2,78 \\
\hline d. Nafsu makan turun & 0 & 0 \\
\hline e. Pusing & $\mathrm{I}$ & 2,78 \\
\hline f. Timbul gatal pada kulit & I & 2,78 \\
\hline g. Jantung berdebar-debar & $\mathrm{I}$ & 2,78 \\
\hline h. Sesak nafas & 0 & 0 \\
\hline \multirow[t]{3}{*}{ i. Lain lain } & $\mathrm{I}$ & 2,78 \\
\hline & (Diar & \\
\hline & e) & \\
\hline Total & 36 & 100 \\
\hline
\end{tabular}

Mayoritas responden (83,3\%) merasakan tidak muncul efek samping obat selama menggunakan obat tradisional. Dari hasil ini dapat disimpulkan bahwa secara empiris, obat tradisional dianggap aman dalam penggunaannya karena efek sampingnya relatif sangat kecil.

Tabel I5. Tindakan Yang Dilakukan Apabila Setelah Menggunakan Obat Tradisional Tetapi Belum Juga Sembuh

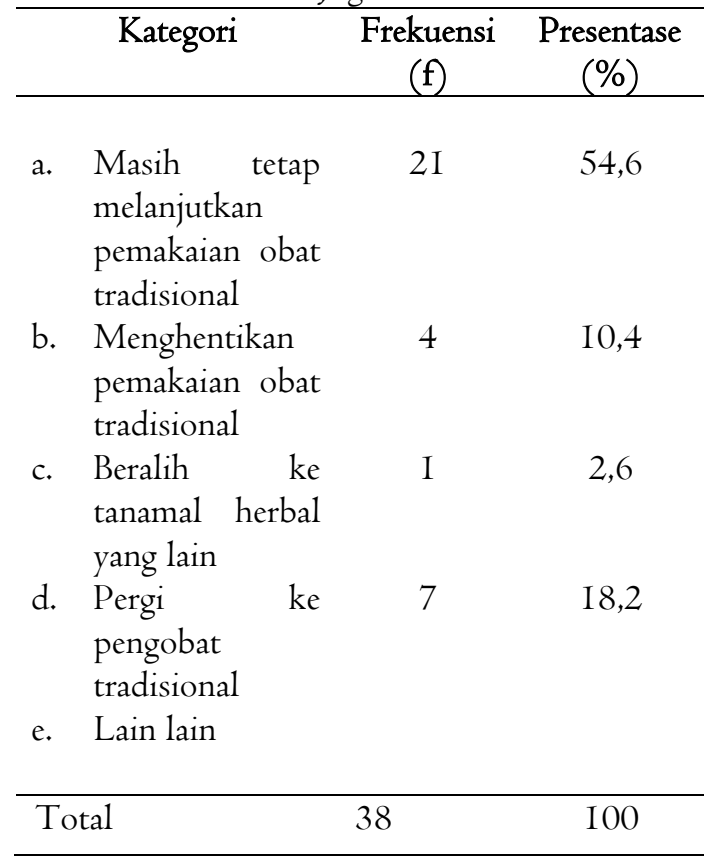

Tabel 15 tentang tindakan yang dilakukan apabila setelah menggunakan obat tradisional tetapi belum juga sembuh. Mayoritas responden Masyarakat (54,6\%) masih tetap melanjutkan pemakaian obat tradisional walaupun belum sembuh. Mereka beranggapan bahwa obat tradisional mengandung bahan-bahan alami dan 
mempunyai efek yang lambat. Penggunaan obat tradisional salah satunya juga untuk menguatkan kondisi tubuh dan meningkatkan daya tahan tubuh. Jadi tetap dikonsumsi walaupun belum sembuh.

Tabel 16. Data Pengetahuan Responden Tentang Manfaat Obat Tradisional Yang Biasa Diminum

\begin{tabular}{ccc}
\hline Kategori & $\begin{array}{c}\text { Frekuen } \\
\text { si (f) }\end{array}$ & $\begin{array}{c}\text { Presentase } \\
(\%)\end{array}$ \\
\hline $\begin{array}{l}\text { a. Tahu manfaat } \\
\text { obat tradisional }\end{array}$ & 29 & 93,5 \\
$\begin{array}{c}\text { b. tidak tahu manfaat } \\
\text { obat tradisional }\end{array}$ & 2 & 6,5 \\
\hline Total & 3I & I00
\end{tabular}

Tabel I6 mengenai data pengetahuan responden tentang manfaat obat tradisional yang biasa diminum. $93,5 \%$ responden mengetahui manfaat obat tradisional yang diminum. Tapi masih ada 6,5\% yang tidak mengetahui manfaatnya.

\begin{tabular}{lcc}
$\begin{array}{l}\text { Pengobatan } \\
\text { Menggunakan Cara Pengobatan Tradisional } \\
\text { Tabel I7. Data Responden Yang Pernah } \\
\text { Menggunakan Cara Pengobatan Tradisional } \\
\text { Untuk Mengobati Penyakit Diderita }\end{array}$ \\
\hline Kategori & $\begin{array}{c}\text { Frekuensi } \\
(\mathrm{f})\end{array}$ & $\begin{array}{c}\text { Presentase } \\
(\%)\end{array}$ \\
\hline & 15 & 39,5 \\
a. Pernah & 23 & 60,5 \\
b. Tidak pernah & & \\
\hline & 38 & 100 \\
\hline
\end{tabular}

Tabel 17 tentang data responden yang pernah menggunakan cara pengobatan tradisional untuk mengobati penyakit diderita. Ternyata hanya $39,5 \%$ yang pernah melakukan. Yang sisanya $(60,5 \%)$ belum pernah melakukan cara pengobatan tradisional.

Tabel 18. Distribusi Jenis Cara Pengobatan Tradisional Yang Dipakai Oleh Responden dan Efek Samping yang Dirasakan.

\begin{tabular}{lccc}
\hline Kategori & $\begin{array}{c}\text { Frekuen } \\
\text { si (f) }\end{array}$ & $\begin{array}{c}\text { Presenta } \\
\text { se (\%) }\end{array}$ & $\begin{array}{c}\text { Efek } \\
\text { sampin } \\
\text { g }\end{array}$ \\
\hline & & & \\
a. Akupunt & I & & - \\
& ur & I I & agak \\
b. Pijat & 3 & & biru, \\
c. Lain lain & 23 & & \\
\hline
\end{tabular}

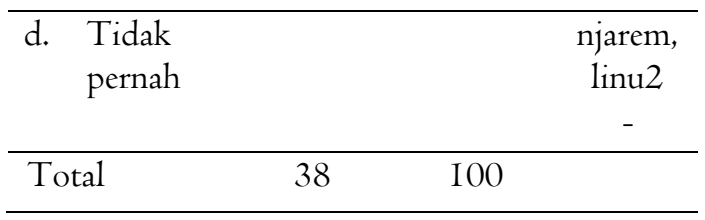

Tabel 18 tentang distribusi jenis cara pengobatan tradisional yang dipakai oleh responden dan efek samping yang dirasakan. Hanya satu yang merasakan efek samping dari cara pengobatan tradisional. Ada efek samping dari pijat tradisional yaitu muncul warna agak biru, njarem dan linu linu.

Tabel 19. Efek Yang Dirasakan Setelah Terapi Menggunakan Cara Pengobatan Tradisional

\begin{tabular}{|c|c|c|}
\hline Kategori & $\begin{array}{l}\text { Frekuensi } \\
\text { (f) }\end{array}$ & Efek yang dirasakan \\
\hline $\begin{array}{l}\text { Merasakan } \\
\text { ada } \\
\text { efeknya }\end{array}$ & $\mathrm{I} 3$ & $\begin{array}{l}\text { a. Rasanya enak, } \\
\text { peredaran darah } \\
\text { lancar } \\
\text { b. Jadi hangat krn } \\
\text { sakit rematik } \\
\text { c. Menghilangkan } \\
\text { capek, } \\
\text { melancarkan } \\
\text { peredaran darah }\end{array}$ \\
\hline & & $\begin{array}{l}\text { d. Badan terasa } \\
\text { ringan }\end{array}$ \\
\hline Tidak & 2 & $\begin{array}{l}\text { e. Meringankan } \\
\text { f. Meringankan } \\
\text { efek krn pernah }\end{array}$ \\
\hline $\begin{array}{l}\text { merasakan } \\
\text { ada }\end{array}$ & & $\begin{array}{l}\text { kena gejala } \\
\text { stroke }\end{array}$ \\
\hline efeknya & & $\begin{array}{l}\text { g. Dibadan enak } \\
\text { h. Dibadan lebih } \\
\text { enak }\end{array}$ \\
\hline
\end{tabular}

Tabel I9 tentang efek yang dirasakan setelah terapi menggunakan cara pengobatan tradisional. Ternyata mayoritas responden merasakan ada efek terapi dari cara pengobatan tradisional. Tetapi ada 2 yang tidak merasakan ada efeknya.

\section{Simpulan dan Saran \\ Simpulan}

Pengetahuan dan pola swamedikasi menggunakan obat tradisional sebagai terapi komplementer pada yandu Wredasari 07, Warungboto, Umbulharjo, Kota Yogyakarta, sesuai dengan keamanan penggunaan obat tradisional dan cara pengobatan tradisional. Terlihat dari data bahwa responden mengetahui khasiat obat dan dosis obat. Dan efek samping yang muncul sangat minimal. 


\section{Saran}

I. Bagi kader Yandu Wredasari 07

Mengingat masih besarnya swamedikasi menggunakan obat tradisional dan cara pengobatan tradisional sebagai terapi komplementer, maka perlu ditingkatkan adanya penyuluhan tentang penggunaan obat tradisional.

2. Bagi responden yang hadir

Setiap hadir ke yandu, dimohon untuk mencari informasi sebanyak banyaknya tentang obat, obat tradisional dan cara pengobatan tradisional yang sedang atau akan dilakukan.

3. Bagi petugas puskesmas UH II

Mengingat rendahnya sumber informasi penggunaan obat tradisional dari tenaga kesehatan (2,6\%), maka sebaiknya lebih ditingkatkan lagi program penyuluhan penggunaan obat, obat tradisional dan cara pengobatan tradisional.

Upaya tersebut bisa juga dilakukan dengan menggalakkan kembali program konseling di berbagai institusi kesehatan baik di rumah sakit, maupun Puskesmas.

\section{Daftar pustaka}

Arikunto, S. (2013). Prosedur Penelitian Suatu Pendekatan Praktik. Jakarta: Rineka Cipta

Depkes, (2006), Acuan Sediaan Herbal, Cetakan Pertama, Departemen Kesehatan RI, Direktorat Jendral Pengawasan Obat dan Makanan, Jakarta.

Ismiyana, (2013), Gambaran Penggunaan Obat Tradisional Untuk Pengobatan Sendiri Pada Masyarakat Di Desa Jimus Polanharjo Klaten, Fakultas Farmasi Universitas Muhammadiyah Surakarta

Kemenkes RI, (2013), Data Riset Kesehatan

Dasar (Riskesdas), Badan Penelitian Dan

Pengembangan Kesehatan, Kementrian Kesehatan RI

Kemenkes RI. (20II). Pengobatan Komplementer Tradisional-Alternatif. http://buk.Depkes.go.id. Kemenkses

Notoatmodjo. (2012). Metodologi penelitian Kesehatan. Jakarta: Rineka Cipta

Permenkes RI, (I993), permenkes No.919/MENKES/PER/X/I993 ttg Kriteria Obat Yang Dapat Diserahkan Tanpa Resep, Menteri Kesehatan RI 